anthropology \& materialism

\section{Anthropology \& Materialism}

A Journal of Social Research

Special Issue | I | 2017

Discontinuous Infinities

\title{
Benjamin, Negativity, and De-vitalized Life
}

\section{Jonathan Short}

\section{(2) OpenEdition \\ Journals}

Electronic version

URL: http://journals.openedition.org/am/802

DOI: $10.4000 / a m .802$

ISSN: 2364-0480

\section{Publisher:}

CETCOPRA, CRASSH - Center for Research in the Arts Social Sciences and Humanities, Fakultät

Gestaltung - Universität der Künste Berlin

Electronic reference

Jonathan Short, «Benjamin, Negativity, and De-vitalized Life », Anthropology \& Materialism [Online], Special Issue | I| 2017, Online since 02 March 2017, connection on 01 May 2019. URL : http:// journals.openedition.org/am/802 ; DOI : 10.4000/am.802

This text was automatically generated on 1 May 2019.

Tous droits réservés 


\title{
Benjamin, Negativity, and De- vitalized Life
}

\author{
Jonathan Short
}

\section{Introduction}

1 If anything is well-established in contemporary theory, it is the idea that humans are essentially non-essential. In this sense, contemporary theory has pursued with particular vigor the project of discrediting the classically (Aristotelian) humanist schema in which humans are defined as rational animals by nature. In the wake of such work it is now a commonplace that, to paraphrase Foucault, the features defining human life are not natural givens, but are themselves at stake in the historical and political activities of human beings. ${ }^{1}$ Humans are understood today as irreducibly reflexive animals whose very activity alters what it means to be human.

2 My intent in this paper ${ }^{2}$ is not to contest this conception of the human being, as it is one of the profound consequences of coming to think of human life historically, which - in turn - is one of the great achievements of modern thought. But, as I will argue here, there are two ways of thinking about the historicity of human being. For reasons I will outline below, I believe one of these ways is superior to the other. In fact, there is a danger attending one form of historical thinking that manifests itself in contemporary strands of philosophical vitalism; in these strands, I contend, non-essentiality is itself surreptitiously converted into something essential through its articulation as an ahistorical property. Against this position, I will argue for the importance of Walter Benjamin's conception of historicity for contemporary theory and politics through what I am going to call his image of 'de-vitalized life'. Benjamin's de-vitalized life presents an image of life stripped of its properties. But the removal of these properties is not about merely de-essentializing life; it is simultaneously the removal of properties in order to foreground the necessity of history as the dimension or medium of human social and political constitution. Accordingly, de-vitalized life serves as a reminder of the 
historically destructive reduction of human life and the necessity of political (class) struggle. Benjamin's image is therefore an index of the need for historical perception and action as the very thing that clears the ground of all positive idols of human nature. Benjamin manifests an acute awareness of the fact that the relation between human being and human history is fragile, in imminent jeopardy of being converted into an ideology of movement toward an already established goal, an essence presupposed and presented as though it were already accomplished. In contrast to this pre-suppositional view, for Benjamin as for Marx, if it is not to become ideological, the human historical essence must always be presented negatively.

\section{An Essentialized Non-Essence}

3 To begin with, it is useful to outline further the parameters of the issue to which I will argue Benjamin's thought contributes. The idea that humans are above all historical beings, so that it is not possible to define them in terms of some given property, is mostly uncontroversial in contemporary theory. The correlate to such a view is that human beings must be defined negatively, i.e. as lacking an essence except where this is selfcreated, and therefore defined by no extant natural property that is not subject to historical making. However, as Roberto Esposito has convincingly argued in Immunitas (2002), there seems to be a discomfort with the negativity of this definition of the human. In response to such discomfort, a philosophical anthropology has appeared, designed to compensate for the negative by converting it into a positive essence. ${ }^{3}$ In this sense, Esposito argues, philosophical anthropology takes over the task once performed by divine theodicy, providing humanity with an interpretative (and thus comforting) self-image. In other words, if it is now impossible to define humanity as relative to the order of nature, i.e. in terms of a statically ascribed property, then philosophical anthropology appears as "the reinstatement of a shattered order" that ascribes to humanity a self-referentially defining property. But as Esposito comments, compensation "brings with it a gain, but never divorced from the loss that it is meant to reinstate". ${ }^{5}$ This form of compensation is never entirely satisfactory because it always refers back to the lack that made it necessary in the first place.

At this point it is possible to bring Esposito's discussion of philosophical anthropology to bear on the relation between contemporary theory and politics. In this respect, as Lorenzo Chiesa has argued provocatively, contemporary variants of ontological vitalism despite the many differences between them - share the common feature of converting human non-essence into a positive property that overlaps with a new type of philosophical anthropology. ${ }^{6}$ According to his analysis, in contemporary theory one finds a move to define the human not by specific attributes, but by positively construed ontological capacities, each of which is carefully portrayed negatively relative to the metaphysical tradition of classical humanism. Here one could mention Catherine Malabou's notion of plasticity ${ }^{7}$ as it appears in her work on neuroplasticity, as well as in her work on Hegel..$^{8}$ One could also mention Michael Hardt and Antonio Negri's notion of a constitutive power in the form of a multitude which undermines the impositions of capitalist biopolitics - a point to which I will return below. ${ }^{9}$ One could even mention Roberto Esposito's own conception of an affirmative biopolitics, which, he suggests, could serve as an antidote to an ascendant biopolitics of immunity. ${ }^{10}$ In all these cases, one finds both the denial of human essence and a conversion of this denial into a new kind of quasi- 
essence - a non-property reconfigured as a generic capacity, which (because it defines the human as such), subsumes the specific conditions of humanity's historical and political form. The overall problem with such post-metaphysical anthropology, in sum, is that it rushes to fill in the gap of non-essential negativity with a positive principle, albeit a dynamic and non-substantive one. At the same time, its political problem seems to be the substitution of a dynamic of history with a semi-naturalistic becoming.

A brief examination of Hardt and Negri's concept of the multitude allows this problem of philosophical anthropology to be grasped more exactly. According to Hardt and Negri, the multitude, which they argue is capable of resisting and overturning capitalist globalization, must be thought on two distinct planes: on the first, the multitude exists as a purely constitutive power, a power of abstract potentiality, while on the second, it exists as contingent historical actualization. However, these "two multitudes", they write, cannot really be separated, since if "the multitude were not already latent and implicit in our social being, we could not even imagine it as a political project; and, similarly, we can only hope to realize it today because it already exists as a real potential" ${ }^{11}$ The theory of the multitude is one in which there are two dimensions of the multitude as a vital constituent power, one an abstract potential and the other an historical actualization, comprising what they describe as "a strange double temporality: always already and notyet". ${ }^{12}$ Drawing on Spinoza, they argue that the multitude in this first sense exists sub specie aeternitatis, and this is what lends to the multitude the sense of existing in the form of an "always-already". ${ }^{13}$

In his incisive critique of Hardt and Negri, Benjamin Noys argues that the concept of the multitude presents an image of a fully developed human essence latent in that part of the multitude that they term "always already". ${ }^{14}$ The problematic consequence of this presupposition, as Noys elaborates, is that present conditions that appear to block the full realization of the multitude become the latter's self-imposed limitations; as Noys writes, the "relation' of two powers is actually a singular nexus in which life as constituent power faces constituted 'power' as the negative limit which it has produced". ${ }^{15}$ If everything is the result of the boundless productivity and constitutive capacity of the multitude, then even what impedes it must be nothing more than its own product at a given historical moment. The political consequence of this notion of the multitude is, as Noys elaborates,

that 'capitalist relations' figure only as the self-imposed limit of the multitude to its own powers: they are its own powers. The collapse of negativity into [the] reversible moment of re-valorisation leaves us at risk of a monism of positivity, in which, despite all the evidence, capital is the mere expression of the underlying power of the multitude. ${ }^{16}$

What Noys' criticism demonstrates is that in this model of non-essentiality, history is placed in a subordinate position with respect to an ontological principle - in this case the living vitality of the multitude - that is presupposed relative to it. Although this vital principle, formally speaking, has no substantive content, and therefore qualifies as nonessential according to the terms of classical humanism, the principle nevertheless surreptitiously provides a content - namely, an abstract image of fully realized human life - that it falls to subsequent historical (social and political) activity to substantialize. But if history already has its work cut out for it, if its task is primarily to realize something pre-given - regardless of how abstract it might be - we cannot truly think history itself as the pure medium of human self-creation, since this medium finds itself already in the debt of something prior which is conceived non-historically, as history's 
other or outside. In other words, Hardt and Negri cannot adequately support their claim that because the multitude does not have a substantive content, it is therefore not a teleological concept. If we concede this point, then Chiesa is quite correct to charge this strand of ontological vitalism with producing what Esposito has called a compensatory philosophical anthropology in the aftermath of classically humanist (substantive) definitions of human nature. In the next section I will draw on a reading of early Marx that avoids this implicit re-essentialization, despite the fact that the young Marx is often read precisely in this essentializing way.

\section{Early Marx}

8 Ironically, even though Hardt and Negri draw extensively on Deleuze and Spinoza thinkers who are deeply hostile to classical humanism - their work on the multitude parallels the humanist reading of early Marx. According to such a reading, what makes the early Marx into a humanist is that he conceives of revolutionary politics as a necessary step for the realization of Gattungswesen ('species-essence', or human nature). As Frank Ruda points out in a recent paper that presents a Badiouian take on Marx's early writings, the humanist reading, much like Hardt and Negri's multitude, "conceives of Marx as the theoretician of the sublation of alienation - a theorist of Ent-Entfremdung which can be achieved because the constitution and disposition of human nature [...] contains all the resources and possibilities which are needed"17 to overcome the alienation of the capitalist mode of production. While the early humanist Marx thus rejects a classically substantive determination of human nature, he nonetheless posits, according to Ruda, "a more general, historically-philosophically, and finally ontologically, secured machinery" 18 for the historical realization of the species.

Nevertheless, as Ruda goes on to argue, it is possible to read the early Marx in a nonhumanist way. ${ }^{19}$ Doing so involves paying attention to Marx's emphasis on history as the medium through which humanity brings itself into existence, and thus displaces the humanist presupposition of a substantive human essence. This non-humanist reading comes into focus when one considers the manner in which it foregrounds certain aspects of Marx's thought, as - for example - in the following passage from the Economic and Philosophical Manuscripts (1844): "Nature as it comes into being in human history - in the act of creation of human society - is the true nature of man; hence nature as it comes into being through industry, though in an estranged form, is true anthropological nature". ${ }^{20} \mathrm{In}$ this passage, a non-humanist reading would emphasize that estrangement is subordinate to the historical action of human self-creation. Estrangement is not the correlate of a true human nature existing already 'offstage', but rather, points toward the possibility that humans might grasp their own historical self-creation as their very species-nature.

It is precisely the question of actualizing the productive historicity of human beings which makes the working class/proletariat distinction of crucial importance in Marx's work. That is, it is only in the process of transforming itself from working class into proletariat (i.e. in actual historical activity) that humanity grasps its essence as a historically self-creating species-being. In order for this to occur, Marx argues, there must exist as its precondition a class of society that is both productive of that society and simultaneously excluded from the determinate categories of membership in that society. This is what the working class is, since the immiserated class of bourgeois/capitalist society is not able to partake of the riches that their labour has made possible, nor can it 
claim membership in humanity as conceived by the bourgeoisie. The latter, by contrast, is a 'proper' class, precisely because it realizes a particular (static) image of humanity as a species of aquisative individuals. As such, however, it is finite and limited, since its image of humanity is mistaken for humanity as such, yet tied to a particular form of social production, namely that of private property and capital accumulation. The working class, on the other hand, in being excluded from this particular form of humanity, is capable from out of the historical circumstances in which it finds itself - of self-cognition as a thoroughly historical class that is capable of universal human production. In other words, the working class contains the germ of a different relationship of humanity to itself, insofar as it recognizes itself not just as an impoverished, excluded, or exploited class (the way it appears in capitalism), but as no class at all, that is, as universal humanity in the generic and negative form of its exclusion from particular (bourgeois) humanity. Only in this universal form can the working class as proletariat then recognize that its historical production is the production of humanity as such, so that its production is able to become the self-aware, universal production of humanity. ${ }^{21}$ In the section below, I turn to Benjamin's work, arguing that his understanding of historical time, examined through the aforementioned concept of 'devitalized life', develops the non-humanist idea of selfcreation we have been exploring via early Marx.

\section{Benjamin and de-vitalized life}

11 It is remarkable that we find, in Benjamin's work, a critique of humanist readings of the early Marx on the one hand, and, on the other, a compelling expansion of the concept of historicity that the non-humanist reading of early Marx presupposes. As I will show in the following, Benjamin's concept of historicity, which is focused on the political figure of 'de-vitalized life', presents an alternative model of non-essentiality that allows history to emerge as the pure medium of human self-production; in marked contrast to a vitalist ontology of life, Benjamin's 'de-vitalized life' remains resolutely negative with respect to all substantive determinations of human being.

12 Accordingly, it is striking how Benjamin poses the problem of the gap between the oppressed working class and the revolutionary proletariat in his theses "On the Concept of History" (1940). In Thesis XII he writes, "[t]he Social Democrats preferred to cast the working class in the role of a redeemer of future generations [...]. This indoctrination made the working class forget both its hatred and its spirit of sacrifice, for both are nourished by the image of enslaved ancestors rather than by the ideal of liberated grandchildren". ${ }^{22}$ Benjamin argues here that the political strength of the working class, which might serve to transform it into the proletariat, lies in a remembrance of what I am calling 'de-vitalized life', that is, an image of ancestors (or predecessors) deprived of a fully human life, rather than of future generations who will enjoy it. What is striking about the image of de-vitalized life is that it is so resolutely negative. The image refuses the utopian promises offered by the social democrats of Benjamin's day and instead arouses, as he puts it, "hatred" and a "spirit of sacrifice" 23 in the working class. The transition from working class to proletariat is not pictured as the progressive unfolding of something already promised - liberated grandchildren whose lives will enjoy full human vitality - but instead involves the deepening of opposition to the existing order, strengthening the proletarian resolve to abolish (negate) capitalist society. It would be tempting at this point to draw a parallel between the social democrats of Benjamin's day 
and the current crop of neo-vitalists. But rather than developing this thought, I will expand instead on the link that Benjamin establishes between the negativity of devitalized life and his concept of historical time, for it is this which gives weight to the former.

As Benjamin writes elsewhere in "On the Concept of History", "our coming was expected on earth. Then like every generation that preceded us, we have been endowed with a weak messianic power, a power on which the past has a claim". ${ }^{24}$ This passage engages in an apparent reversal of perspective when compared to the one previously cited. If previously Benjamin emphasized a political remembrance of the de-vitalized lives of the past by proletarian subjects of the present, he now suggests that the de-vitalized lives of the past have a claim on those who come after them. But how can those who are already dead be said to retain a claim on the present, and what sort of a claim could it be? If the force of remembrance lies with the past's expectations or even anticipations of the present, then this suggests that something more than the empirical memories of the historical heirs is at play here.

To get at what sort of claim the past has on the present for Benjamin, it is instructive to consider his essay of 1923, "The Task of the Translator". Herein we find a theory of translation, articulated as a force of transposition, which sheds light on the relation between generations that I intimated above. According to Benjamin, translation is first of all a question of linguistic communicability or impartibility (Mitteilbarkeit) before it is a question of the content communicated or transmitted. This is why Benjamin states that neither the original texts, nor their translations, exist for the sake of their recipients, but just the opposite: the recipient is only a party to "meaningful" communication in an indirect way, as the contingent addressee of imparting itself. As Benjamin writes, "[t]he question of whether a work is translatable has a dual meaning. Either: Will an adequate translator ever be found among the totality of its readers? Or, more pertinently: does its nature lend itself to translation and, therefore, in view of the significance of this form, call for it?"25 Benjamin answers his question by claiming that, while the answer to the first question can only be an empirical one, the answer to the second must be answered "apodictically", that is, a priori. ${ }^{26}$

15 In the context of making his transcendental point about language, Benjamin provides an analogy that seems to portend his future discussion of remembrance of 'devitalized lives' in 1940. He writes: "[o]ne might, for example, speak of an unforgettable life or moment even if all men had forgotten it. If the nature of such a life or moment required that it be unforgotten, that predicate would imply not a falsehood but merely a claim unfulfilled by men." ${ }^{27}$ In an obviously Kantian sense, this parallel between translation and remembrance places the latter on the same 'transcendental terrain' as translation itself, thus foreshadowing Benjamin's subsequent work on history and remembrance. As Werner Hamacher comments in his kaleidoscopic reading of Benjamin's translation essay, "translatability and unforgettability are essential predicates of a language or a life, in principle indifferent to the capacities of any given subject to fulfill them" ${ }^{28}$ As the transcendental condition for any possible translation, the demand for translatability and remembrance outstrips the empirical "horizon of finite experience" even while remaining "operative within this horizon as calls back to the ground of experience itself, to a realm of speech and action ecstatically removed from understanding as a structure of judgment and correspondence". ${ }^{29}$ Thus, language remains translatable and memory remains memorable, even in the absence of the finite capacities of particular human 
subjects, even if in empirical terms they cannot be translated or remembered. If this is indeed the case, then neither translatability nor memorability consist principally in the transmission of contents or memories (i.e. of subjective experiences) between subjects through time, but rather in a transcendental demand for translation and for remembrance. Here, the very impartibility (Mitteilbarkeit) of works (and, by extension, lives) constitutes the demand of and for translation and memory, even if - at the level of empirical experience - the work goes untranslated and the life remains unremembered.

It would be possible to go further in this direction and to suggest that, for Benjamin, history itself is the medium of this demand, that history is nothing other than the impartibility (Mitteilbarkeit) - the medium of the demand for remembrance - of works and lives. This would mean that the essence of such mediality is to exceed all possible (empirical) reception, translation or remembrance, even as it makes it possible. ${ }^{30}$ Thus, as Hamacher writes, if "something's essence defines it" as possible, then this same essentiality "indefines it and infinitizes it - as a demand infinitely in excess of every propositional actuality". ${ }^{11}$ This being-infinitely-in-excess produces, equally, "the possibility of - and demand for - an impossibility of translation, the possibility of - and demand for - untranslatability". ${ }^{32}$ If the translatability of language is the precondition (medium) of all communication, and history is the condition of all remembrance, then it is also possible that language will not be translated and lives will be forgotten.

What Hamacher calls the infinite demand for translation is fundamentally connected to what Benjamin describes as the Überleben or 'outliving', and the Nachleben or afterlife, of works and indeed of lives. If the essence of language is translation and that of history is memorability, then language and memory are already beyond themselves, never confined to a single work or life. Thus the essence cannot be thought of as something discreet bound to an abstract linear point in time - but only as inherently in-finitized, selfabandoned, because it is self-transmuting and transmitting. Such outliving-afterlife is not to be confused with a hyper-vitality that allows works and lives to somehow escape their destruction and death, but rather precisely the opposite: their perishing is the very hallmark of their essentially being-beyond-themselves, and it is this feature that makes them translatable and memorable. Because of this we might say that remembrance is integrally related to translation. If the essence of language is translation, (i.e. transposition and non-coincidence), then in remembrance (which requires the medium of language) lives lost are re-membered or re-composed, leaping across their own noncoincidence or lack and taking on a different, unpredictable, but relational existence, for later generations.

If this is accurate, then remembrance also configures historical temporality in what Benjamin later calls a constellation. In this sense, the afterlife of language and the afterlife of lives can be articulated in terms of Benjamin's famous depiction of the dialectical image, in the Passagen-Werk, as the relational disconnection (the apparent oxymoron is deliberate) of then and now. As Benjamin writes: "[i]t is not that what is past casts its light on what is present, or what is present its light on what is past; rather, image is that wherein what has been comes together in a flash with the now to form a constellation". ${ }^{33}$ Either of the first two alternatives would be but another version of historicism, an attempt to think both past and present in a linear and causal way. But it is against just this linear image of historical remembrance that Benjamin portrays the relation between past and present generations in the theses "On the Concept of History" as a "weak messianic power". ${ }^{34}$ 
Thus, as Benjamin stipulates in the passage cited above, such a messianic power of remembrance is a weak power. The weakness here does not imply a lesser capacity or a power of reduced degree, but as we can now see, a factor of contingency. Benjaminian remembrance is not merely a counter-history, a history told from the perspective of the oppressed and downtrodden that would simply reverse the historical position of the victors. The specific power of 'blasting' that removes lives from the continuum of history that seemed to make their fate inevitable supplies much more than a merely linear narrative, no matter how unflattering to the ruling class; it also carries with it an affective, transitive charge, which disrupts and interrupts the self-assured way of understanding the course of time. However, like all such charges, it is unpredictable and can "flash up" only at that precisely "dangerous" moment when it is capable of being recognized by those in the present. ${ }^{35}$ But even though Benjamin writes in the PassagenWerk that "each 'now' is the now of a particular recognizability", ${ }^{36}$ this is far from a prediction that explosive remembrance will result in the necessary political action. In fact, as we have seen, such contingency seems to be demanded by the very messianic structure of remembrance itself. If remembrance and translation share the same underlying structure, partake of the same demand that structures historical time, then remembrance cannot be thought to directly grasp messianic time as such. Indeed, if messianic time is just this transcendentally medial demand of impartibility, as temporalization, then the latter provides merely the occasion or site (the demand of imparting), but never the guarantee, of messianic remembrance.

To take this last point a little bit further, the explosive remembrance that potentially leads to political revolution is clearly distinguished by Benjamin from any kind of messianic presence or realization of a messianic state or condition. This is perhaps another sense in which we can speak of a 'de-vitalized life': empirical remembrance, even if it issues in revolutionary politics, must be distinguished sharply from the messiah as a figure of secular eschatology. To dispel this potential confusion, it will be enough to compare two of Benjamin's texts that get at this point. In his preparatory notes for the theses "On the Concept of History", the so-called "Paralipomena", Benjamin maintains that "[w]hoever wishes to know what the situation of 'redeemed humanity' might actually be, what conditions are required for the development of such a situation, and when this development can be expected to occur, poses [a] question[s] to which there are no answers" ${ }^{37}$ This statement corresponds to another formulation in an earlier text, the "Theological-Political Fragment" (c. 1921), where Benjamin expresses a very similar sentiment with respect to the messiah. There he writes that "nothing that is historical can relate itself, from its own ground, to anything messianic". ${ }^{38}$ Benjamin's theological language in this early text, which nonetheless parallels the political language he uses in the later "Paralipomena", equally maintains that the Kingdom of God "is not the telos of the historical dynamic; it cannot be established as a goal". ${ }^{39}$ In both texts Benjamin insists that it is never a question of ending historical time by bringing about a utopian (timeless) condition. This is the case not only because a future order of universal humanity is unknowable in present circumstances, but more importantly, because messianic time is vulgarized if it is thought to be a mere moment on the time-line of the present order. Such a conception fails to understand that messianic time is not on the order of sequential becoming, and is in this sense not something realizable; rather, such time is fundamentally 'untimely' because it never appears as the result of a causal historical sequence. In this regard, the image of future society in Benjamin's work relentlessly 
cleaves to the negative image of the future. Consistent with this insight, 'de-vitalized life', despite its brief appearance in Benjamin's theses, is not an image of a better or 'redeemed' humanity corresponding to a messiah who has arrived, or whose coming is promised. Instead of this, in contrast to the promissory images of vitalized life, 'devitalized life' refers us to history as negative, without content, and thus disquietingly open.

\section{Conclusion}

What we have just been considering throws into relief one of the main issues dividing vitalist-inspired philosophies from Benjamin's image of de-vitalized life and his concept of messianic history. The first, as we saw in the case of Negri, thinks the moment of revolution or politics in terms of a constituent power that is already behind the scenes and simply has to appear. It is thus a model of self-realization or actualization out of selfalienation, not unlike the humanist reading of early Marx. In contrast to this, as Benjamin - and indeed the anti-humanist version of early Marx - insists, history must be understood as the creatio ex nihilo that produces the not-yet from what has so far transpired. There is something discomfiting about this conception, since it takes away any promises that such a transformation will occur; contingency rather than certainty becomes the driving force of historical representation. Rather than the thinker of 'mystical' compensations, which he is sometimes portrayed as providing, Benjamin makes political disappointment into a transcendental possibility. In this sense, the image of devitalized life is useful as a counter-image to the various vitalist concepts of superabundant life. In contrast to these, Benjamin notes in his "Theological-Political Fragment" that "nature is Messianic by reason of its eternal and total passing away". ${ }^{40}$ This passage suggests that it is precisely because the messianic moment includes historical destruction (negation) that it is not only the opposite of temporal passing away. The passing away that we can locate in de-vitalized life is not just the sheer reduction or negation of life, but the transience of the living that is related, through passing away, to the weak messianic power of historical time, and through it, to the infinitizing demand for transformation. Such transformation is never certain because Benjamin introduces a gap between the course of profane history and messianic time, even as he seeks to articulate their connection. It is in this uncertain movement of displacement and connection, whose motion must be traversed negatively and without promises, that human species-essence is recognizable as what it is: as fully historical life.

\section{BIBLIOGRAPHY}

BENJAMIN, Walter, Selected Writings 1, 1913-1926, eds. Marcus Bullock \& Michael W. Jennings (Cambridge, MA: Belknap Press of Harvard University Press, 1996).

BENJAMIN, Walter, Selected Writings 3, 1935-1938, eds. Howard Eiland \& Michael W. Jennings (Cambridge, MA: Belknap Press of Harvard University Press, 2006). 
BENJAMIN, Walter, Selected Writings 4, 1938-1940, eds. Howard Eiland \& Michael W. Jennings (Cambridge, MA: Belknap Press of Harvard University Press, 2003).

BENJAMIN, Walter, The Arcades Project, trans. Howard Eiland, Kevin McLaughlin (Cambridge, MA: Belknap Press of Harvard Univ. Press, 1999).

CHIESA, Lorenzo, Human, Inhuman, Humanism: Badiou and Sartre, Lecture, York University, Toronto, Canada, 20 January 2014.

ESPOSITO, Roberto, Bios: Biopolitics and Philosophy, trans. Timothy Campbell (Minneapolis: Minnesota University Press, 2008).

ESPOSITO, Roberto, Immunitas: The Protection and Negation of Life (Boston: Polity Press. 2011).

FOUCAULT, Michel, History of Sexuality, Vol. 1 (New York: Vintage, 1990).

HAMACHER, Werner, “Intensive Languages”, in: MLN, 127, 3, (2012), pp. 485-451.

MALABOU, Catherine, The Future of Hegel: Plasticity, Temporality and Dialectic (London: Routeledge, 2004).

MALABOU, Catherine, What Should We Do With Our Brain? (New York: Fordham University Press, 2008)

MARX, Karl, Early Writings (London: Penguin Books, 1974).

NEGRI, Antonio \& HARDT, Michael, Multitude: War and Democracy in an Age of Empire (London: Penguin Books, 2011).

NEGRI, Antonio \& Hardt, Michael, Commonwealth (Cambridge, MA: Harvard University Press, 2011).

NOYS, Benjamin, The Persistence of the Negative: A Critique of Contemporary Continental Theory (Edinburgh: Edinburgh University Press, 2010).RUDA, Frank, "Humanism Reconsidered, or: Life Living Life", in: Filozofski Vestnik, 30, 2 (2009), pp. 175-193.

\section{ENDNOTES}

1. Michel Foucault, "The Right of Death and Power over Life", in: History of Sexuality, Vol. I (New York: Vintage, 1990).

2. I would like to thank Jan Sieber and Sebastian Truskolaski for their helpful editorial suggestions and comments on a previous draft of this paper.

3. Roberto Esposito, Immunitas: The Protection and Negation of Life (Boston: Polity Press, 1990).

4. Esposito, Immunitas, p. 81.

5. Ibid.

6. Lorenzo Chiesa, Human, Inhuman, Humanism: Badiou and Sartre, Lecture, York University, Toronto, 20. January 2014.

7. Catherine Malabou, What Should We Do with Our Brain? (New York: Fordham University Press, 2009).

8. Catherine Malabou, The Future of Hegel: Plasticity, Temporality, and Dialectic (London: Routledge, 2006).

9. Michael Hardt and Antonio Negri, Multitude: War and Democracy in the Age of Empire (London: Penguin Books, 2006).

10. Roberto Esposito, Bios: Biopolitics and Philosophy (Minneapolis: University of Minnesota Press, 2006). 
11. Hardt and Negri, Multitude, p. 222.

12. Ibid.

13. Ibid.

14. Benjamin Noys, The Persistence of the Negative: A Critique of Contemporary Continental Theory (Edinburgh: Edinburgh University Press, 2010).

15. Ibid, p. 112.

16. Ibid, p. 114.

17. Frank Ruda, “Humanism Reconsidered, or: Life living life”, in: Filozofski Vestnik (2009), p. 177.

18. Ibid, p. 177.

19. Ruda emphasizes that his non-humanist reading is distinct from the anti-humanist reading provided by Althusser and others. It is thus not completely hostile to some version of (nonclassical) humanism.

20. Karl Marx, "Economic and Philosophical Manuscripts of 1844", in: Early Writings (London: Penguin Books, 1974), p. 355.

21. Although my phrasing differs from Ruda's Badiouian language, the point I am making runs parallel with his reading. As Ruda argues, the proletariat is "inexistent" in the conditions of bourgeois society since it is both a local possibility and a universal impossibility. Only the political abolition of that state would make universal human self-production real. See Ruda, “Humanism Reconsidered", pp. 190-191.

22. Walter Benjamin, "On the Concept of History", in: Selected Writings 4, 1938-1940, eds. Howard Eiland \& Michael W. Jennings (Cambridge, MA: Belknap Press of Harvard University Press, 2003), p. 394.

23. Ibid, p. 394.

24. Ibid, p. 390.

25. Walter Benjamin, “On the Task of the Translator”, in: Selected Writings 1, 1913-1926, eds. Marcus Bullock \& Michael W. Jennings (Cambridge, MA: Belknap Press of Harvard University Press, 1996), p. 254.

26. Ibid.

27. Ibid.

28. Werner Hamacher, “Intensive Languages”, in: MLN, 127, 3 (2012), p. 488.

29. Ibid.

30. While I do not have the space here to treat this matter in sufficient detail, Benjamin's approach to language consists of a re-worked but still recognizable Kantian transcendentalism. Much of the basis for this approach can be found in Benjamin's 1917 essay "On the Program of the Coming Philosophy". In this early essay he argues that while the Kantian approach to the justification of knowledge (by which he means the derivation of experience from its transcendental conditions) is sound, Kant fetters his approach by confining experience to what is possible for a subject under conditions of Newtonian natural science. (See Walter Benjamin, Selected Writings 1, 1913-1926, eds. Marcus Bullock \& Michael W. Jennings [Cambridge, MA: Belknap Press of Harvard University Press, 1996], pp. 100-110). Since experience is fettered in this way, Benjamin maintains, the transcendental condition of all experience will be displaced toward a transcendental subject at the limit of empirical experience. In fact, since this transcendental subject still depends on language for its categorical judgments, it is language itself (and not the subject) that should occupy the position of the transcendental condition of possible experience. In turn, the existence of language acts as a portal to a new experience of temporality. Needless to say, this has the effect of making language as such transcendental, noumenal in the Kantian sense.

31. Hamacher, "Intensive Languages", p. 491.

32. Ibid.

33. Walter Benjamin, The Arcades Project, trans. Howard Eiland, Kevin McLaughlin (Cambridge, MA: Belknap Press of Harvard University Press, 1999), p. 453. 
34. Benjamin, "On Concept of History", p. 390.

35. Ibid.

36. Benjamin, The Arcades Project, p. 463.

37. Walter Benjamin, "Paralipomena to Concept of History", in: Selected Writings, 1938-1940, eds. Howard Eiland \& Michael W. Jennings (Cambridge, MA: Belknap Press of Harvard University Press, 2003), p. 402.

38. Benjamin Walter, "Theological-Political Fragment", in: Selected Writings 3, 1935-1938, eds. Howard Eiland \& Michael W. Jennings (Cambridge, MA: Belknap Press of Harvard University Press, 2006), p. 305.

39. Benjamin, "Paralipomena", p. 402.

40. Benjamin, “Theological-Political Fragment”, p. 306.

\section{ABSTRACTS}

This paper contends that Walter Benjamin's image of life as 'de-vitalized' allows history to be thought negatively, as open and without promises or guarantees. This negative conception of history provides a valuable counterpoint to the prevalent variants of neo-vitalist thought that continue to think human being in terms of an abstract (vital) property to be realized historically. By refusing an image of redeemed humanity, Benjamin, like the early Marx, shows that the concept of history is necessary for thinking humanity non-essentially, and that, if it is to avoid becoming an abstract essence, historical time must be thought negatively.

\section{INDEX}

Keywords: Benjamin Walter, vitalism, Marx Karl, historical time, non-essentialism, politics, Esposito Roberto, Hardt and Negri

\section{AUTHOR}

\section{JONATHAN SHORT}

York University Toronto, Canada 